\title{
ISOLASI SENYAWA ANTIOKSIDAN DAN ANTIBAKTERI DARI EKSTRAK DAUN TEH- TEHAN (Acalypha siamensis) SERTA PENDEKATAN AKTIVITAS MELALUI STUDI IN SILICO
}

\author{
${ }^{1}$ Dimas Ade Setyawan, \\ ${ }^{1}$ Program Studi Farmasi, Fakultas Sains dan Teknologi, Universitas Ma Chung, 65151 Malang, \\ Jawa Timur, Indonesia.
}

Email korespodensi : $\underline{611610005 @ \text { student.machung.ac.id }}$

\begin{abstract}
Abstrak
Seiring dengan meningkatnya jumlah penyakit akibat radikal bebas dan infeksi bakteri yang terjadi di negara berkembang sebagai penyebab salah satu masalah kematian di Indonesia. Tumbuhan asli Indonesia bernama daun Tehtehan memiliki potensi sebagai tanaman obat telah digunakan sebagai sebagai antibakteri pada tahap ekstrak. Isolasi senyawa aktif perlu dilakukan untuk mengidentifikasi struktur dan aktivitasnya sehingga dapat dilakukan penentuan dosis. Isolasi senyawa aktif dilakukan dengan menggunakan metode kromatografi lapis tipis dengan fase diam silica gel dan fase gerak methanol:kloroform:heksan (7:2:1). Senyawa murni yang telah didapatkan dikarakterisasi strukturnya dengan menggunakan spektrofotometer UV/Vis dan inframerah, serta spektrometer massa dan resonansi magnetik inti (NMR). Penambatan molekul dilakukan dengan menggunakan program PyRx dan divisualisasikan menggunakan program Discovery Studio. Hasil interpretasi menunjukkan senyawa aktif (E)-3-(1Hindol3yl)1(4methoxyphenyl)-prop-2en-1-one. Senyawa tersebut memiliki aktivitas antioksidan yang sangat kuat dengan nilai $\mathrm{IC}_{50}$ sebesar 42,54369 ppm dengan menggunakan metode DPPH. Uji aktivitas antibakteri menunjukkan adanya aktivitas sedang pada $S$. aureus dengannilai zona penghambatan 1,6-2 cm. Uji secara in silico menunjukkan bahwa senyawa tersebut mampu berinteraksi dengan baik dengan protein superoxide dismutase (SOD), glutathione peroxidase (GPX), peptidoglycan glycosyltransferase (PGT) dan Dalanyl Dalanine carboxypeptidase (DACA) dengan melakukan penambatan molekul (molecular docking).
\end{abstract}

Kata kunci: daun teh-tehan, isolasi, antioksidan, antibakteri, penambatan molekul

\footnotetext{
Abstract

The increasing number of diseases caused by free radicals and bacterial infections that occur in developing countries as a cause of death problems in Indonesia. Indonesian native plant called Tehtehan leaf has potential as a medicinal plant which has been used as an antibacterial at the extract stage. Isolation of active compounds needs to be done to identify the structure and activity so that the determination of the dose can be done
}

Isolation of active compounds was carried out using thin layer chromatography methods with the silica gel stationary phase and the mobile phase of methanol: chloroform: hexane (7: 2: 1). The pure compounds that have been obtained are characterized by using UV / Vis and infrared spectrophotometers, as well as mass spectrometers and core magnetic resonance (NMR). Molecular docking is done using the PyRx program and visualized using the Discovery Studio program. The results of the interpretation show the active compound (E) 3- (1Hindol-3-yl) -1- (4methoxyphenyl) -prop-2-en-1one.The compound has a very strong antioxidant activity with an $I C_{50}$ value of 42.54369 ppm using the DPPH method. Antibacterial activity test showed moderate activity in S. aureus with inhibition zone values of 1.6-2 $\mathrm{cm}$. In silico tests showed that the compound was able to interact well with protein superoxide dismutase (SOD), glutathione peroxidase (GPX), peptidoglycan glycosyltransferase (PGT) and Dalanyl-D-alanine carboxypeptidase (DACA) by inhibiting molecular docking (molecular docking).

Keyword: Acalypha siamensis, isolation, antioxidants, antibacterial, molecular docking

\section{PENDAHULUAN}

Seiring dengan meningkatnya jumlah penyakit akibat radikal bebas dan infeksi bakteri yang terjadi di negara berkembang sebagai penyebab salah satu masalah kematian di Indonesia (Wahyono, 2007). Permasalahan dalam pemakaian antibiotik yang tidak tepat serta karena paparan mikroorganisme pada tubuh menjadi pemicu terjadinya penyakit. Sebagai contoh terjadinya resistensi bakteri. Resistensi terjadi sebagai akibat dari pemakaian antibiotik yang tidak tepat dosis, macam dan lama pemberian (Brahma \& Marak, 2012). Sedangkan penyakit infeksi disebabkan karena jenis patogen dan faktor risiko yang menyertainya (Dye, 2015). Antibakteri merupakan senyawa yang berfungsi untuk membunuh atau menghambat pertumbuhan reproduksi bakteri. Suatu zat antibakteri yang baik harus memiliki sifat toksisitas yang selektif, dimana obat tersebut berbahaya untuk parasit tetapi tidak membahayakan sel inang. Mekanisme kerja 
dari bakteri ini dapat bekerja membunuh pertumbuhan bakteri atau yang disebut dengan bakteriosida dan bekerja menghambat pertumbuhan bakteri atau yang disebut dengan bakteriostatik. (Talaro, 2008). Antioksidan adalah suatu senyawa yang pada konsentrasi rendah secara signifikan dapat menghambat atau mencegah oksidasi substrat dalam reaksi rantai (Halliwell dan Whitemann, 2004; Leong dan Shui, 2002). Antioksidan bekerja melalui mekanisme transfer atom hidrogen dan transfer elektron tunggal. Antioksidan dapat melindungi selsel dari kerusakan yang disebabkan oleh molekul tidak stabil yang dikenal sebagai radikal bebas. Antioksidan dapat mendonorkan elektronnya kepada molekul radikal bebas, sehingga dapat menstabilkan radikal bebas dan menghentikan reaksi berantai.

Ekstraksi merupakan suatu proses pemisahan senyawa aktif dari beberapa campuran senyawa dengan menggunakan pelarut yang sesuai (Mukhriani, 2014). Dalam hal ini, selama proses ekstraksi berlangsung fungsi dari pelarut adalah sebagai cairan penyerap metabolit sekunder agar dapat keluar dari dalam sel tumbuhan atau simplisia. Salah satu metode ekstraksi yang sederhana yaitu maserasi, dimana metode ini dilakukan dengan cara simplisia dimasukkan kedalam suatu wadah tertutup kemudian direndam dengan larutan penyari dan didiamkan pada suhu ruangan. Isolasi merupakan metode pemisahan senyawa aktif berdasarkan perbedaan tingkat polaritasnya (Manz et all, 2004). Metode isolasi yang biasanya digunakan yaitu kromatografi lapis tipis, dimana proses pemisahan berdasarkan tingkat kelarutannya pada fase diam dan pada fase gerak yang menggunakan campuran pelarut untuk dapat membawa senyawa aktif melewati fase diam.

Indonesia memiliki kekayaan alam terbesar di dunia yaitu 30.000 spesies diantaranya 7.500 spesies sudah diketahui manfaat herbalnya (Munadi, 2017). Salah satu tanaman obat yang berpotensi sebagai antioksidan dan antibakteri yaitu tanaman teh-tehan (Acalypha siamensis). Namun, sekarang ini masih terbatas pemanfaatannya, dimana masyarakat hanya menggunakan tanaman ini sebagai pagar atau pakan hewan ternak. Namun secara empiris digunakan sebagai obat malaria, dan pelancar peredaran darah (Hariana, 2013). Sedangkan secara science sudah dibuktikan bahwa esktrak etanolik daun tehtehan menunjukkan aktivitas antifungi pada jenis Candida albicans (Rohmatika, 2017). Berdasarkan penelitian yang telah dilakukan oleh Pertiwi (2018), ekstrak etanolik daun tehtehan (Acalypha siamensis) mengandung senyawa Fenolik dan Flavonoid. Untuk mengetahui kemampuan dari senyawa aktif sebagai antioksidan dan antibakteri maka perlu dilakukan pengujian penambatan molekul. Pengujian ini merupakan salah satu metode pengembangan obat berdasarkan pendekatan struktur dimana metode yang digunakan yaitu docking molekul yang berfokus pada interaksi antara ligan dan protein. Pada uji ini dikenal sebagai uji in silico dimana akan menghasilkan nilai binding energy untuk mengetahui kemampuan senyawa aktif tersebut untuk berikatan. Semakin kecil nilai binding energy maka semakin stabil ikatan tersebut dan memiliki aktivitas yang kuat.

\section{METODE Alat dan Bahan}

Peralatan yang digunakan dalam penelitian ini meliputi oven, lempeng KLT, toples kaca, dan chamber KLT. spektrofotometer inframerah, spektrometer massa, spektrometer HNMR, dan spektrometer C-NMR, spektrofotometer UV-Vis, bunsen, jarum ose, cawan petri, tabung reaksi, micropipette, yellow tip dan blue tip, laminar air flow (LAF), serta inkubator. Laptop yang dilengkapi dengan aplikasi Chemdraw Ultra 8.0, Discovery Studio 4.0 dengan Autodock Vina, PyRx.

Bahan yang digunakan antara lain daun Tanaman teh-tehan (Acalypha siamensis) serbuk silica gel 60 GF254, lempeng silica gel 60 GF245, etil asetat, metanol $80 \%$, nheksan, kloroform, reagen 2,2diphenyllpicrylhydrazyl (DPPH), bakteri Eschericia coli, Staphylococcus aureus, Nutrient Agar, Nutrient Broth (Sigma), standar McFarland dibuat dengan mencampurkan larutan $\mathrm{BaCl}_{2}$ dengan $\mathrm{H}_{2} \mathrm{SO}_{4}$ dan dimetilsulfoksida (DMSO), protein glutathione peroxidase (GPX), superoxide dismutase (SOD), peptidoglycan glycosyltransferase (PGT), dan DalanylDalanine carboxypeptidase (DACA).

\section{Ekstraksi}

Dalam melakukan proses ekstraksi, terlebih dahulu dilakukan preparasi simplisia kering dengan cara memanaskan tumbuhan yang diuji ke dalam oven. Setelah simplisia kering dapat dilakukan ekstraksi dengan metode maserasi dimana simplisia direndam dengan pelarut metanol dengan perbandingan (1:4) kemudian didiamkan pada suhu ruang selama 3 hari. Proses maserasi ini dilakukan pengulangan (remaserasi) sebanyak 3 kali. Setelah itu dilakukan filtrasi untuk memisahkan cairan yang mengandung senyawa aktif dengan ampas simplisia. Kemudian dilakukan penguapan dengan rotary evaporator untuk menghilangkan sisa pelarut yang masih terkandung dalam cairan dan dikeringkan di waterbath hingga diperoleh ekstrak kental.

\section{Isolasi}

Proses isolasi dilakukan dengan tahapan awal yaitu optimasi fase gerak. Dalam tahap ini dilakukan uji coba pada berbagai macam jenis campuran fase gerak untuk mengetahui fase gerak mana yang sesuai untuk dijadikan sebagai pelarut untuk proses isolasi. Jenis fase gerak yang digunakan antara lain metanol : kloroform : heksan (7:2:1), metanol ; klorofom (3:1), etil asetat : heksan $(8: 2)$, etil asetat : heksan : butanol $(7: 2: 1)$, etil asetat : heksan : kloroform (7:2:1), etil asetat : heksan ; metanol (7:2:1). Setelah diperoleh jenis fase gerak yang sesuai maka dilanjutkan dengan kromatografi lapis tipis preparatif. Sebanyak 55 gram serbuk silica gel $\mathrm{GF}_{254}$ dilarutkan kedalam $110 \mathrm{ml}$ aquades kemudian dituangkan pada alat TLC plate coater dan diratakan pada permukaannya, ditunggu hingga kering. Kemudian dilakukan aktivasi pelat KLT dengan cara pemasan menggunakan oven pada suhu $100^{\circ} \mathrm{C}$ selama 1 jam.

Selanjutkan dilakukan pengenceran ekstrak dengan cara $100 \mathrm{mg}$ ekstrak dilarutkan dalam $2 \mathrm{ml}$ metanol. Dilakukan 
penotolan pada pelat KLT sebanyak 5x dan dilanjutkan dengan proses elusi menggunakan 2 jenis fase gerak yaitu metanol : kloroform : heksan (7:2:1) dan etil asetat : heksan (8:2). Setelah proses elusi berakhir maka dilihat pada lampu UV366. Setelah diperoleh adanya spot pemisahan maka dilakukan pengerokan bagian spot yang berpotensi sebagai antioksidan dan antibakteri. Dilakukan penyaringan dengan menggunakan metanol : kloroform (1:1) untuk memisahkan silica gelnya dan dikeringkan yang selanjutnya digunakan sebagai sampel uji. Dialnjutkan dengan uji kemurnian isolat menggunakan KLT 2 dimensi.

\section{Uji Aktivitas Antioksidan}

Uji aktivitas antioksidan menggunakan reagen DPPH dilakukan dengan cara preparasi larutan DPPH 100 ppm yang dibuat ditimbang $10 \mathrm{mg}$ DPPH dilarutkan dalam $100 \mathrm{ml}$ metanol. Preparasi larutan sampel uji dengan cara ditimbang 10 mg dilarutkan $10 \mathrm{ml}$ metanol. Selanjutnya dilakukan pengenceran sampel uji dibuat 5 seri kosentrasi yaitu $(100 ; 200 ; 300 ; 400 ; 500)$ ppm dengan cara dipipet

$(0,2 ; 0,4 ; 0,6 ; 0,8 ; 1)$ ad $2 \mathrm{ml}$ dari masingmasing larutan dipipet $0,2 \mathrm{ml}$ dan ditambahkan 3,8 ml larutan DPPH. Setelah itu, dilakukan pengenceran kembali dengan konsentrasi $(10 ; 20 ; 30 ; 40 ; 50)$ ppm dengan cara dipipet masing-masing larutan sebayak $1 \mathrm{ml}$ ad $10 \mathrm{ml}$ metanol. Dan dibuat larutan kontrol yang berisi larutan DPPH. Kemudian didiamkan selama 30 menit dan dibaca absorbansinya menggunakan spektrofotometer UV-Vis pada panjang gelombang $517 \mathrm{~nm}$. Kemudian ditentukan nilai $\mathrm{IC}_{50}$ untuk mengetahui kemampuan aktivitas antioksidannya.

\section{Uji Aktivitas Antibakteri}

Uji aktivitas antibakteri dilakukan dengan cara preparasi alat dan bahan sebelum digunakan dengan cara sterilisasi menggunakan autoklaf pada suhu $121^{\circ} \mathrm{C}$ selama 15 menit. Disiapkan media Nutrien Agar (NA) dan Nutrien Broth (NB) dengan cara ditimbang 2 gram NB dan 2 gram NA dilarutkan dengan $250 \mathrm{ml}$ aquades yang panas pada masingmasing media lalu dilarutkan sampai homogen. Jenis bakteri uji yang digunakan yaitu Eschericia coli dan Staphylococcus aureus metode yang dilakukan yaitu KLT Bioautografi yang dilakukan dengan cara menempelkan pelat KLT yang sudah ditotolkan senyawa uji pada media NA yang sudah berisi bakteri uji. Kemudian dilihat aktivitasnya setelah 24 jam.

Pada penentuan kadar hambat minimum (KHM) dilakukan dengan metode mikrodilusi broth. Metode ini dilakukan dengan cara membuat seri konsentrasi larutan uji 1000; 2000; dan $4000 \mathrm{mg} / \mathrm{L}$ dengan menggunakan pelarut DMSO 0,2\%. Kemudian dilakukan pengenceran menggunakan Nurtient Broth (NB) steril dengan seri konsentrasi tertentu (tabel 3.1). Selanjutnya dilakukan pencampuran larutan dalam wadah microtube yang terdiri dari $50 \mu \mathrm{L}$ media NB; $50 \mu \mathrm{L}$ suspensi bakteri uji dengan kekeruhan setara dengan standar McFarland 0,5; dan $100 \mu \mathrm{L}$ larutan isolate. Dalam pengujian ini dibuat kontrol isolat, kontrol bakteri uji, kontrol media dan kontrol positif. Kontrol isolat dengan cara sebanyak $100 \mu \mathrm{L}$ pada masingmasing seri konsentrasi ditambahkan $100 \mu \mathrm{L} \mathrm{NB}$ steril. Kontrol bakteri uji yang digunakan yaitu suspensi bakteri sebanyak $200 \mu \mathrm{L}$. Kontrol media yang digunakan yaitu NB steril sebanyak $200 \mu \mathrm{L}$. Sedangkan kontrol positif yang digunakan yaitu streptomisin dengan konsentrasi 10 $\mathrm{mg} / \mathrm{mL}$ sebanyak $100 \mu \mathrm{L}$ dan bakteri ujisebanyak $100 \mu \mathrm{L}$. Hasil dari pengujian ini dapat diamati setelah dilakukan inkubasi selama 24 jam pada suhu $37^{\circ} \mathrm{C}$. Penentuan nilai KHM dapat ditunjukkan sebagai konsentrasi isolat terkecil yang mampu menghambat pertumbuhan bakteri uji, dimana ditandai dengan adanya larutan jernih. Sedangkan untuk penentuan kadar bunuh minimum (KBM), dapat

dilakukan dengan cara mengambil setiap cairan pada microtube dengan menggunakan mikropipet menggunakan seri konsentrasi $(200 ; 400 ; 600 ; 800 ; 1600$ dan 2000 ppm) seri larutan dan uji kontrol positif dengan menggunakan obat streptomycin dan kontrol negatif dengan menggunakan media NA dan pelarut DMSO. lalu dieteskan pada mikro disc pada media Nutrient Agar (NA). penentuan nilai KBM ini dapat ditunjukkan pada saat setelah diinkubasi pada suhu $37^{\circ} \mathrm{C}$ selama 24 jam sebagai terbentuknya larutan yang jernih.

Tabel 3.1 Pengenceran Larutan Isolat

No. Konsentr Volum Volum Konsentra asi e e NB si Akhir
Larutan Laruta Steril Larutan
Isolat
n (m) (m) Isolat
(mgolat $(\mathrm{mg} / \mathrm{L})$

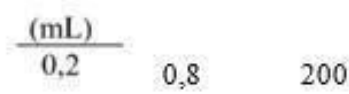

Elusidasi Struktur

Elusidasi struktur dari senyawa hasil sintesis didasarkan pada data spektra UVvis, inframerah, spektra massa dan H-NMR dan C-NMR. Kemudian dilakukan analisis hasil dari masing-masing spektra sehingga diperoleh nama dari struktur senyawa hasil uji secara spesifik

Uji In Silico

Preparasi Struktur Molekul Ligan

Senyawa A dilakukan preparasi dengan menggunakan software Chemdraw Ultra 8.0 dan 
Chemdraw 3D Ultra 8.0. dalam struktut ligan tersebut harus dilakukan minimize energy dengan cara klik menu MM2 7 minimize energy $\boldsymbol{\theta}$ run. Setelah dipreparasi molekul ligan disimpan dalam satu folder dengan format pdb sesuai dengan namannya.

\section{Preparasi Struktur Protein Target}

Protein target yang digunakan yaitu glutation peroksidase (GPX), superoksida dismutase (SOD), peptidoglikan glukositransferase (PG), D-alanil Dalanin dekarboksipeptidase (DACA). Keempat senyawa ini di download dari Protein Data Bank (PDB) (http://www.rcsb.org). Dalam melakukan preparasi molekul target di preparasi dengan software Discovery Studio 4.1 yang dilakukan adalah penghilangan gugus $\mathrm{H} 2 \mathrm{O}$, pemisahan ligan alami dan penambahan atom hidrogen yang dilakukan dengan cara klik menu script $\boldsymbol{\nabla}$ selection select water molecules / ligand / protein chains $\mathbf{7}$ edit $\boldsymbol{\nabla}$ delete. Setelah dipreparasi, molekul target dan ligan alami yang telah dipisahkan disimpan dalam satu folder engan format .pdb

\section{Penentuan Sisi Aktif Protein Target}

Dalam penentuan sisi aktif protein target merupakan tempat berikatannya ligan dengan senyawa golongan flavonoid. Pada penelitian ini dilakukan pencarian sisi aktif tempat berikatnnya ligan dengan protein target yang menggunakan software PyRx dengan prinsip pencarian energi ikatan terkecil dari ikatan molekul $\mathrm{H} 2 \mathrm{O}$ di seluruh radius molekul protein target

\section{Penambatan Molekul}

Dalam melakukan penambatan molekul dari senyawa flavonoid akan menjadi ligan dengan protein menggunakan software PyRx dengan sistem Autodock Vina. Struktur makromolekul dan ligan yang telah dioptimasi secara terpisah disimpan dalam satu folder yang sama. Proses docking dimulai dengan cara klik menu file $\boldsymbol{\nabla}$ load molecule $\boldsymbol{\nabla}$ cari folder tempat penyimpanan ligan dan protein. Setelah semua file tersedia kemudian di klik kanan $\boldsymbol{8}$ pilih AutoDock $\boldsymbol{\theta}$ ligand (untuk ligan yang akan diuji) dan makromolekul untuk protein yang diuji. Di bagian Vina Wizard klik start here $\boldsymbol{7}$ pilih local (apabila belum tertandai) $(7$ start. Pada tampilan select molecules, dipastikan ligan dan macromolecule selected, sebab ketika ligan dan makromolekul belum dipilih maka akan berakibat langkah selanjutnya tidak dapat diforward. Namun, Apabila belum dipilih bagian add ligan atau add molecule dapat dipilih atau pada bagian AutoDock dapat diblok bagian ligan yang ingin diuji ataupun bagian makromolekul 8 diforward 8 run vina. Di bagian selanjutnya terdapat gridbox yang dapat diatur pada tabel view, diarahkan pada binding site sebagai titik tengah, kemudian dicatat koordinat x,ydan z. Kemudian diklik run vina, maka proses docking akan dimulai dan tunggu hingga 100\% maka hasil akan muncul pada tabel analyze result. Klik ligand out dengan binding affinity terkecil kemudian pada tabel navigator akan klik molecule pilih ligand out yang telah diklik di tabel analyze result, kemudian klik kanan save as
PDB. Validasi metode docking terhadap ligan asli dilakukan untuk mencari konformasi 3D ligan asli terhadap reseptor dengan memperhatikan koordinat pusat masa struktur dan besaran gridbox dari binding site pocket dalam satuan angstrom (Vina) atau number of points (AutoDock). Konformasi hasil docking yang diperoleh disejajarkan dengan konformasi ligan asli hasil pengukuran kristalografi yang dinyatakan dalam nilai root mean square deviation (RMSD). Hasil penelitian sebelumnya, nilai RMSD untuk kesejajaran konformasi struktur yang masih dapat diterima adalah kurang dari 5, semakin mendekati nilai 0 maka nilai kesejajaran semakin baik. (Saputri et al.2016).

\section{Analisa Hasil Penambatan Molekul}

Dari hasil proses penambatan molekul akan diperoleh nilai skor binding energy dalam satuan $\mathrm{kkal} / \mathrm{mol}$ yang didapat dari senyawa flavonoid dengan molekul target dibandingkan dengan hasil/skor binding energy molekul docking antara ligan asli dengan reseptor. Jika hasil/skor binding energy dari senyawa flavonoid lebih kecil daripada ligan asli maka senyawa tersebut dapat disimpulkan bahwa senyawa flavonoid tersebut memiliki aktivitas untuk bersaing dalam berikatan di molekul target. Hasil/skor binding energy yang terbaik yang diperoleh dari penambatan molekul dapat ditampilkan dalam bentuk tabel dan kemudian di visualisasikan tempat berikatannya dan jenis ikatan molekulnya secara 2 dimensi (2D) dengan software Discovery Studio Visualizer. Tujuannya adalah untuk melihat residu asam-asam amino yang terlibat dan ikatan yang terjadi antara senyawa yang diteliti dengan target protein. Ikatan yang terjadi terutama pada sisi aktif yaitu pada asam amino yang sesuai akan dijadikan prediksi sementara serta kemampuan senyawa derivate yang tertambat pada molekul protein sasaran yang terbesar akan dijadikan sebagai dasar penentuan senyawa dengan aktivitas terbaik.

\section{HASIL DAN PEMBAHASAN Hasil Ekstraksi Simplisia}

Proses ekstraksi simplisia dilakukan dengan menggunakan metode maserasi. Metode maserasi ini dilakukan pada suhu ruang sehingga selama proses ekstraksi dapat memperkecil risiko yang berdampak pada hasil ekstraksi. Hal ini dikarenakan apabila dilakukan pada kondisi panas selama ekstraksi dapat menyebabkan degradasi pada produkproduk yang termolabil. Mekanisme kerja dari metode maserasi dalam penarikan senyawa yaitu dengan pelunakan dinding sel tumbuhan dan pelarutan sneyawa pada suhu ruang seingga gradien konsentrasi memiliki peranan penting dalam menghasilkan proses yang efisien. Hasil ekstraksi akan menghasilkan ekstrak kental dengan karakteristik berwarna hijau. Proses ekstraksi yang dilakukan menghasilkan jumlah rendemen sebesar $12,38 \%(\mathrm{~b} / \mathrm{b})$. 


\section{Hasil Isolasi Senyawa Aktif dengan Kromatografi Lapis Tipis}

Proses pemisahan dilakukan dengan menggunakan metode Kromatografi Lapis Tipis (KLT) fase normal dan menggunakan fase gerak berupa kombinasi metanol : kloroform : n-heksana (7:2:1). Pemisahan dengan menggunakan jenis fase gerak tersebut dapat menghasilkan pemisahan yang baik. Pemisahan pelat KLT dapat diamati dibawah cahaya tampak sinar UV254 dan UV366 namun karena lampu UV254 tidak ada maka yang diamati hanya pada lampu UV366. Setelah diamati dapat menunjukkan 6 pita pemisahan. Hasil dari pemisahan senyawa ditunjukkan pada gambar 4.1 dan nilai faktor retensi (Rf) untuk masingmasing pita ditunjukkan pada tabel 4.1.

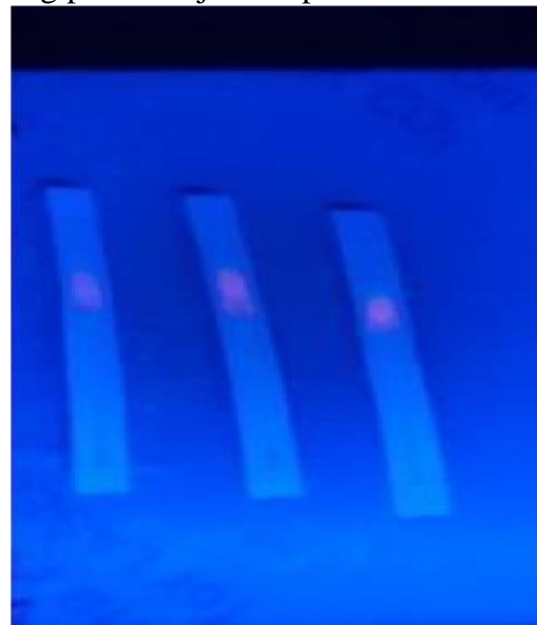

Gambar 4.1 Hasil Pemisahan Senyawa dengan

Menggunakan Metode KLT pada sinar UV366

Tabel 4.1 Nilai Rf pita yang terdeteksi pada Pelat

\begin{tabular}{cc}
\hline Sampel & Nilai Rf \\
\hline Fraksi 1 & 0,5625 \\
Fraksi 2 & 0,625 \\
Fraksi 3 & 0,650 \\
Fraksi 4 & 0,6875 \\
Fraksi 5 & 0,775 \\
Fraksi 6 & 0,8125 \\
\hline
\end{tabular}

Pemisahan dengan menggunakan fase gerak nonpolar memiliki risiko naiknya senyawa pigmen klorofil. Fraksi-fraksi yang terdeteksi pada rentang nilai $\mathrm{Rf}<0,5$ memiliki warna hijau kekuningan di bawah cahaya tampak dan berfluorosensi menjadi merah di bawah sinar UV366. Fluorosensi pada rentang Rf tersebut dimungkinkan berasal dari senyawa klorofil yang terdapat dalam ekstrak (Kusmita et al, 2015). Akan tetapi, adanya jarak nilai Rf yang cukup jauh memungkinkan proses isolasi lebih lanjut dengan menggunakan fase gerak methanol : kloroform : heksan (7:2:1). Proses penampisan senyawa aktif dilakukan melalui tahap bioautografi dan pengamatan bercak dengan reagen semprot DPPH.

\section{Penampisan Senyawa Aktif pada Pelat KLT}

Pada penampisan senyawa antioksidan dan antibakteri dilakukan pada pelat KLT yang telah dielusi. Kemudian ditentukan aktivitas antibakterinya dengan menggunakan metode bioautografi, dimana metode ini dapat mendeteksi keberadaan senyawa antibakteri pada kromatogram. Pada metode bioautografi ini dilakukan pengujian pada bakteri Escherichia coli dan Staphylococcus aureus. Hal ini dilakukan untuk dapat membandingkan mekanisme kerja dari senyawa aktif lebih efektif bekerja pada jenis bakteri gram positif atau bakteri gram negatif. kemudian berdasarkan hasil uji antibakteri tersebut, dapat diketahui bahwa fraksi 6 memiliki senyawa aktif antibakteri bakteri Staphylococcus aureus. Sementara hasil uji aktivitas antibakteri pada Escherichia coli tidak ditemukan.

Pada penampisan senyawa antioksidan dilakukan dengan cara menyemprotkan larutan DPPH 0,2 mg/ml pada permukaan kromatogram KLT. Hal ini dapat diketahui senyawa antioksidan ditunjukkan dengan adanya pita atau bercak putih. Hasil pemeriksaan dengan menggunakan pelat KLT berukuran 1 x $10 \mathrm{~cm} 2$ tidak menunjukkan hasil yang terlalu baik, namun masih dapat diidentifikasi bahwa terdapat senyawa antioksidan yang terkandung di dalam kromatogram. Hasil uji tersebut dapat dilihat pada gambar 4.2.

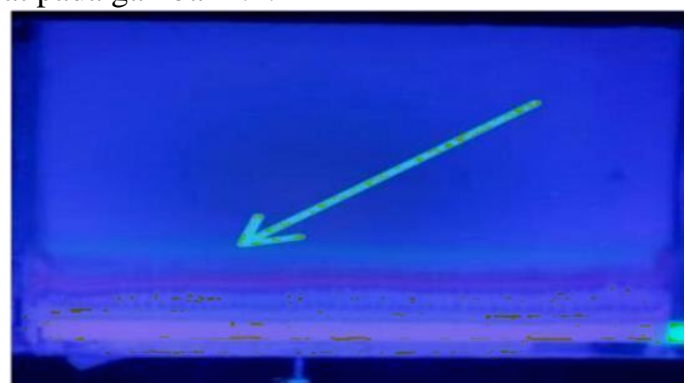

Gambar 4.2 Hasil Uji Penampisan Senyawa Antioksidan pada Pelat KLT

Terjadi perubahan warna yang dapat diamati yaitu warna kuning dan putih yang menandakan senyawa uji memiliki aktivitas antioksidan dalam pelat KLT. Dengan demikian, senyawa antioksidan yang dibutuhkan untuk bereaksi dengan seluruh DPPH yang diaplikasikan pada pelat KLT lebih mudah diamati.

\section{Perbanyakan Fraksi dengan Metode KLT Preparatif}

Proses isolasi senyawa aktif dilanjutkan dengan menggunakan metode kromatografi lapis tipis preparatif (KLTP). Pemisahan ini dapat dilakukan dengan menggunakan pelat kaca berukuran $20 \times 19 \mathrm{~cm}^{2}$ yang telah dilapisi dengan silica gel $\mathrm{GF}_{254}$. Sebelum dilakukan proses elusi maka pelat silica gel tersebut harus diaktivasi terlebih dahulu dengan menggunakan oven dengan suhu $115^{\circ} \mathrm{C}$ selama 1 jam. Hal ini bertujuan untuk mengurangi jumlah kandungan air sehingga Selma proses pemisahan dapat terjadi dengan baik. Proses elusi dilakukan selama kurang lebih 45 menit dalam 1 siklus dan akan berhenti ketika proses elusi sudah mendekati batas atas pelat KLT silica gel. Hasil pemisahan dengan menggunakan metode KLT preparative menunjukkan adanya 6 pita yang terpisah namun masih berdekatan. Setelah dilakukan proses elusi dialnjutkan dengan pengumpulan fraksi isolat dengan cara pengerokan silica gel yang telah dielusi di tempat spot yang akan diambil. Kemudian silica gel dan fraksi isolate 
dipisahkan dengan cara melarutkan ke dalam campuran metanol : kloroform (1:1). Selanjutnya dilakukan penyaringan untuk memisahkan padatan silika gel dengan senyawa terlarut, sehigga yang akan dianalisis hanya senyawa aktifnya saja tanpa terdapat kandungan silica gel.

\section{Uji Kemurnian Fraksi Isolat}

Pada pengujian kemurnian isolat dilakukan dengan menggunakan metode Kromatografi Lapis Tipis 2 Dimensi. Pada KLT 2 dimensi eluen yang digunakan pada penotolan pertama dengan eluen yang kedua setelah diputar 900 yang berbeda. Kemudian hasil isolat ditotolkan pada pelat KLT yang selanjutnya dielusi dengan menggunakan fase gerak metanol : kloroform : heksan $(7: 2: 1)$. Setelah itu dilihat hasilnya apakah terdapat noda atau bercak tunggal pada pelat KLT. Hasil menunjukkan bahwa terdapat 1 noda pada masing-masing jenis isolat $\mathrm{A}$ dan isolat $\mathrm{B}$ sehingga dapat dikatakan bahwa isolat tersebut memiliki senyawa tunggal.
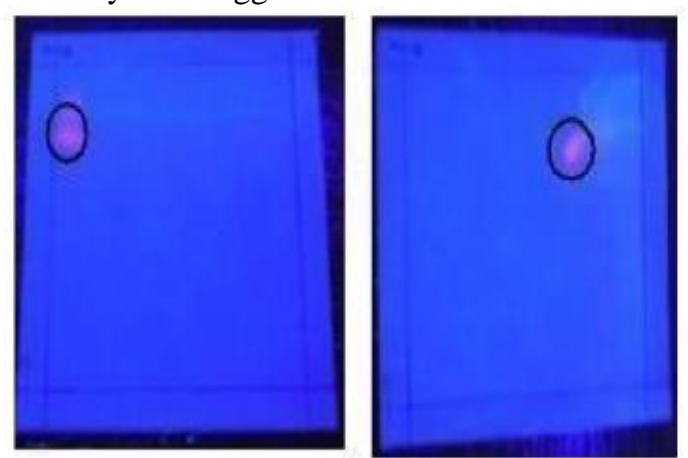

Gambar 4.3 Hasil Uji Kemurnian Isolat A dan Isolat B

Serapan maksimum pada isolat A dengan Panjang gelombang $267 \mathrm{~nm}$ menunjukkan bahwa isolat A memiliki ikatan rangkap terkonjugasi yang pendek dan menunjukkan transisi eklektronik n ke $\sigma^{*}$ dari ikatan karbonil $(\mathrm{C}=\mathrm{O})$. Pada pergeseran panjang gelombang $250300 \mathrm{~nm}$ menunjukkan adanya gugus karbonil aldehid dan keton jenuh (Solomon,1997). Berdasarkan hasil nilai Panjang gelombang tersebut dapat dihipotesiskan bahwa senyawa pada isolat A memiliki ikatan rangkap terkonjugasi dan merupakan senyawa golongan flavonoid/lakton (AlOmary, 2017).

\section{Intepretasi Spektrum Inframerah Karakterisasi Struktur Isolat Intepretasi Spektrum UV-Vis}

Pada pembacaan spektrum UV-Vis dapat dilakukan untuk menentukan dan mengetahui keberadaan ikatan rangkap terkonjugasi pada senyawa uji. Senyawa uji ini yang mengandung ikatan rangkap terkonjugasi akan mengalami eksitasi pada kondisi energi transisi tertentu. Spektrum pada masing-masing isolat A dapat dilihat pada gambar 4.4 hasil spektrum pada isolat A ditemukan pada panjang gelombang $267 \mathrm{~nm}$.

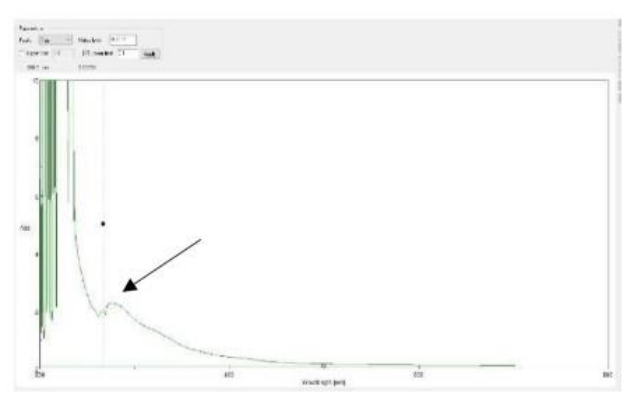

bilangan gelombang pada masing-masing puncak yang terbaca disertai dengan prediksi adanya gugus hidroksil pada senyawa yang

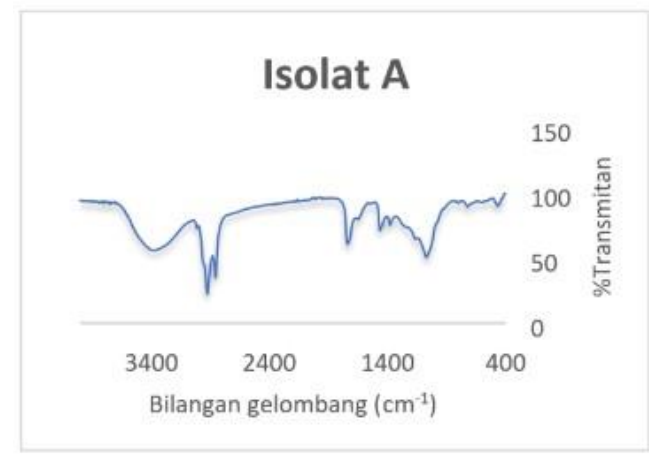

Gambar 4.5 Spektrum Inframerah Isolat A

Tabel 4.2 Puncak yang terdeteksi pada Spektrum Inframerah dari Isolat A

\begin{tabular}{ccc}
\hline $\begin{array}{c}\text { Bilangan } \\
\text { Gelombang } \\
\left(\mathrm{cm}^{-1}\right)\end{array}$ & Intensitas & $\begin{array}{c}\text { Prediksi Gugus } \\
\text { Fungsi }\end{array}$ \\
\hline 3393,1375 & Kuat & O-H (alkohol/fenol) \\
2920,6631 & Kuat & C-H \\
2852,2026 & Kuat & C-H
\end{tabular}

Ditunjukkan oleh puncak kuat pada bilangan gelombang $3393,1375 \mathrm{~cm}^{-1}$ dan pada pembacaan dari isolat A yang dibaca dengan menggunakan metode pelat $\mathrm{KBr}$ dan pada table 4.2 menunjukkan gugus fungsi yang terkandung dalam senyawa tersebut. Pada pembacaan spektrum inframerah menunjukkan adanya gugus-gugus fungsi yang terdapat didalam senyawa uji. Pada gambar menunjukkan spektrum inframerah

$\begin{array}{lll}1730,7991 & \text { Sedang } & \mathrm{C}=\mathrm{C} / \mathrm{C}=\mathrm{O} \text { (asam karbolsilat/karbonil) } \\ 1653,6604 & \text { Lemah } & \mathrm{C}=\mathrm{C} / \mathrm{C}=\mathrm{O} \text { (asam karboksilat/karbonil) } \\ 1455,9926 & \text { Sedang } & \mathrm{C}-\mathrm{C} \\ 1375,9612 & \text { Sedang } & \mathrm{C}-\mathrm{H} \\ 1067,4065 & \text { Sedang } & \mathrm{CO} \text { (lakton) } / \mathrm{O}-\mathrm{H} \\ 718,3539 & \text { Lemah } & \mathrm{C}-\mathrm{OH}\end{array}$

Pada pembacaan spektrum inframerah pada isolat A menunjukkan $718,3539 \mathrm{~cm}^{-1}$ Keberadaan gugus C-H diperkuat dengan adanya serapan pada bilangan gelombang 2920,6631; 2852,2026; 1375,9612 sedangkan pada bilangan gelombang $1067,4065 \mathrm{~cm}^{-1}$ menunjukkan gugus $\mathrm{C}-\mathrm{O}$ (lakton). keberadaan gugus $\mathrm{C}=\mathrm{C} / \mathrm{C}=\mathrm{O}$ diperkuat dengan adanya serapan pada bilangan gelombang 1730,7991 dan $1653,6604 \mathrm{~cm}^{-1}$ mununjukkan gugus karbonil. sementara itu, serapan 
lain pada bilangan gelombang 1455,9926 cm-1 mengindikasikan terdapat gugus fungsi C-C. Dengan demikian isolat A dapat dihipotesiskan sebagai suatu senyawa hidrokarbon yang mengandung gugus hidroksil, karbonil dan lakton.

\section{Intepretasi Spektrum ${ }^{1} \mathrm{C}-\mathrm{NMR}$}

Pada spektrum 13C-NMR dilakukan untuk mengetahui jumlah atom $\mathrm{C}$ dan jenis atom $\mathrm{C}$ dari isolat $\mathrm{A}$. Dalam rangka mendapatkan gambaran yang lebih jelas mengenai bentuk struktur isolat A diperlukan informasi mengenai jenis-jenis atom penyusunnya. Senyawa hidrokarbon memiliki komposisi atom karbon dalam strukturnya sehingga pengenalan tentang jenis atom karbon dalam senyawa dapat membantu proses karakterisasi struktur isolat A yang merupakan salah satu senyawa hidrokarbon. Jenis atom karbon yang terdapat pada senyawa uji ditentukan melalui

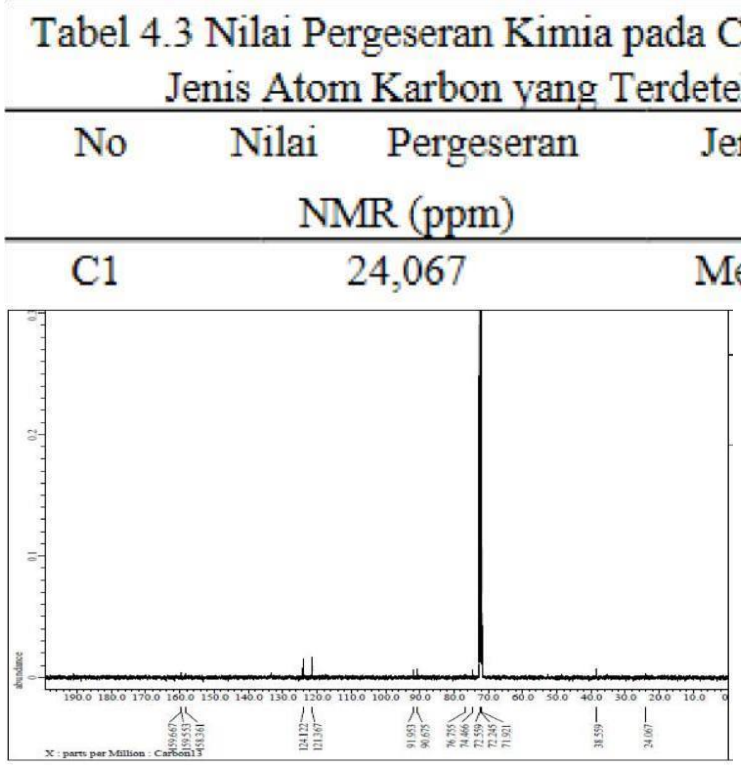

metode spektrometri resonansi magnetik inti karbon. Tabel 4.3 menunjukkan nilai pergeseran kimia pada CNMR dan usulan jenis gugus karbon penyusun senyawa kimia pada

\begin{tabular}{|c|c|c|}
\hline $\mathrm{C} 2$ & 38,559 & $\operatorname{Metin}(\mathrm{CH})$ \\
\hline $\mathrm{C} 3$ & 71,921 & $\operatorname{Metin}(\mathrm{CH})$ \\
\hline $\mathrm{C} 4$ & 72,245 & $\operatorname{Metin}(\mathrm{CH})$ \\
\hline $\mathrm{C} 5$ & 72,559 & $\operatorname{Metin}(\mathrm{CH})$ \\
\hline $\mathrm{C} 6$ & 74,466 & $\operatorname{Metin}(\mathrm{CH})$ \\
\hline C7 & 76,755 & $\operatorname{Metin}(\mathrm{CH})$ \\
\hline $\mathrm{C} 8$ & 90,675 & $\begin{array}{l}\text { Karbon olefinik } \\
\qquad(\mathrm{C}=\mathrm{C})\end{array}$ \\
\hline $\mathrm{C} 9$ & 91,953 & $\begin{array}{l}\text { Karbon olefinik } \\
(\mathrm{C}=\mathrm{C})\end{array}$ \\
\hline $\mathrm{C} 10$ & 121,367 & $\begin{array}{l}\text { Karbon } \\
\text { aromatis }\end{array}$ \\
\hline $\mathrm{C} 11$ & 124,122 & $\begin{array}{l}\text { Karbon } \\
\text { aromatis }\end{array}$ \\
\hline $\mathrm{C} 12$ & 158,361 & Karbonil $(\mathrm{C}=\mathrm{O})$ \\
\hline $\mathrm{C} 13$ & 159,553 & Karbonil $(\mathrm{C}=\mathrm{O})$ \\
\hline $\mathrm{C} 14$ & 159,667 & $\begin{array}{l}\text { Karbonil } \\
(\mathrm{C}=\mathrm{O})\end{array}$ \\
\hline
\end{tabular}

${ }^{1} \mathrm{C}-$
Namun, untuk mengetahui jenis atom karbon apakah termasuk dalam jenis karbon metil, metilen atau metin masih tidak dapat ditentukan hal ini dikarenakan tidak adanya informasi yang dapat mendukung jenis karbon tersebut seperti informasi adanya DEPT yang dapat ditentukan secara pasti dari jenis karbon tersebut, sehingga penelitian ini masih dapat dikatakan sebagai hipotesis ditemukannya jenis karbon tersebut.

\section{Intepretasi Spektrum ${ }^{1} \mathrm{H}-\mathrm{NMR}$}

Posisi atom-atom karbon dapat ditentukan secara lebih spesifik dengan memanfaatkan pengenalan terhadap jenis dan multiplisitas atom hidrogen yeng melekat pada atom karbon tersebut. Posisi atom-atom hidrogen pada senyawa uji dideteksi melalui metode spektrometri resonansi magnetik inti. Tabel 4.4 menunjukkan hasil pengamatan terhadap pergeseran atom hidrogen, multiplisitas, jumlah, dan prediksi jenis gugus karbon tempat hidrogen berikatan.

Tabel 4.4 Nilai Pergeseran Kimia pada ${ }^{1} \mathrm{H}-\mathrm{NMR}$ dan Jenis Atom Karbon yang Terdeteksi

$\begin{array}{lll}\text { No } & 8 \mathrm{H} ; \text { multiplisitas } & \text { Usulan gugus } \\ 1 & 1,23 ; \mathrm{s} & \mathrm{CH}_{3} \\ 2 & 1,62 ; \mathrm{t} & \mathrm{CH} \\ 3 & 2,09 ; \mathrm{s} & \mathrm{CH} \\ 4 & 2,69 ; \mathrm{dd} & \mathrm{CH} \\ 5 & 3,09 ; \mathrm{dd} & \mathrm{CH} \\ 6 & 3,91 ; \mathrm{s} & \mathrm{CH} \\ 7 & 5,41 ; \mathrm{t} & \mathrm{CH} \\ 8 & 5,75 ; \mathrm{s} & \mathrm{CH} \\ 9 & 5,99 ; \mathrm{m} & \mathrm{CH}\end{array}$

Gambar 4.7 Spektrum ${ }^{1} \mathrm{H}-\mathrm{NMR}$ Isolat A

Terpisah dengan baik dan beberapa puncak yang memiliki multiplisitas kompleks. Dua puncak tertinggi terbaca pada pergeseran, Pada spektrum ${ }_{1} \mathrm{H}-\mathrm{NMR}$ dapat kimia 7,25 dan 7,41 ppm sebagai suatu doublet juga terdeteksi pada pergeseran kimia 2,69 dan 3,09 ppm yang mengindikasikan adanya atom hidrogen yang melekat pada atom karbon dalam lingkungan heteroatom. Berdasarkan jumlah dan nilai pergeseran kimianya, atom hidrogen tersebut diindikasikan melekat pada atom karbon yang berdekatan dengan atom oksigen dan karbon olefinik (C8 dan C9).

\section{Intepretasi Spektrum Massa}

Pada spektrum fragmentasi massa menunjukkan massa ion-ion fragmen yang terbentuk akibat adanya potensial listrik yang diaplikasikan pada senyawa uji. Pada spektrofotometri massa ini digunakan metode Electrospray Ionization (ESI) dimana dalam metode ini peak dengan \%abudance tertinggi merupakan base peak. Berdasarkan hasil penentuan massa molekul dapat diketahui bahwa ion $[\mathrm{M}+\mathrm{H}]+$ memiliki nilai $\mathrm{m} / \mathrm{z}$ sebesar $278,88 \mathrm{~g} / \mathrm{mol}$ sehingga nilai massa molekul isolat A adalah $277,88 \mathrm{~g} / \mathrm{mol}$. Pada proses pembacaan massa fragemen ion terdapat hubungan antara fragmen dengan nilai m/z 256,89 dan 534,90 g/mol. 
Namun apabila kedua fragmen tersebut dikurangi akan menghasilkan nilai fragmen 278,88 sehingga dapat dikatakan bahwa nilai massa molekul dari senyawa A adalah $[\mathrm{M}+\mathrm{H}]$ yaitu $277,88 \mathrm{~g} / \mathrm{mol}$. Ketika massa molekul suatu senyawa memiliki bilangan ganjil maka dapat dikatakan bahwa senyawa tersebut memiliki atom nitrogen. Hal ini dibuktikan dengan ditunjukkannya pada spektrum H-NMR pada pergesaran kimia 11,93 ppm.

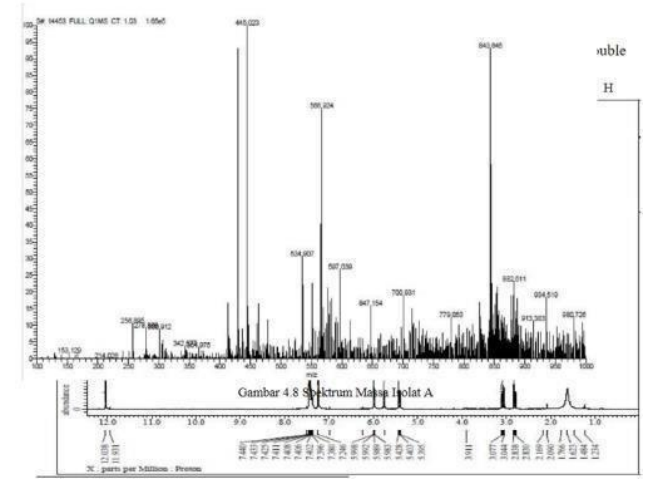

\section{Kesimpulan Hasil Elusidasi Struktur}

Berdasarkan hasil penggabungan interpretasi data spektrum UV-Vis, IR, MS, dan NMR dihipotesiskan bahwa isolat A memiliki struktur polisiklik dari golongan lakton (kalkon). Hal ini dibuktikan dengan hasil-hasil yang ditujukkan pada masing-masing spektra. Pada spektrum UVVis diketahui memiliki Panjang gelombang maksimal pada $267 \mathrm{~nm}$ yang menunjukkan adanya gugus karbonil $(\mathrm{C}=\mathrm{O})$ dan termasuk ke dalam senyawa golongan flavonoid (lakton). Pada spektrum IR diketahui adanya gugus karbonil pada bilangan gelombang $1730,7991 \mathrm{~cm}^{-1}$ serta gugus lakton (C-O) pada bilangan gelombang 1067,4069 cm-1. Pada spektrum C-NMR diketahui adanya karbon aromatis (benzena) pada C10 dan C11 dengan pergeseran kimia 121,367 dan 124,122 ppm, serta ditemukan juga jenis karbonil pada C12-C14 dengan pergeseran kimia 158,361159,667 ppm. Pada spektrum HNMR diketahui adanya gugus amina $(\mathrm{NH})$ pada pergeseran kimia 11,93 ppm. Pada spektrum massa diketahui berat molekul isolat A pada spekta $277,88 \mathrm{~g} / \mathrm{mol}$. Penamaan struktur menunjukkan bahwa isolat A memiliki nama kimia (E)-3(1Hindol-3-yl)-1(4methoxyphenyl)prop2en1-one yang selanjutnya disebut dengan senyawa A. Senyawa A ini memiliki berat molekul $277,289 \mathrm{~g} / \mathrm{mol}$ dengan rumus kimia

3-yl)-1-(4-methoxyphenyl)-prop-2-en-1-one $\mathrm{C}_{18} \mathrm{H}_{15} \mathrm{NO}_{2}$ dan memiliki struktur molekul

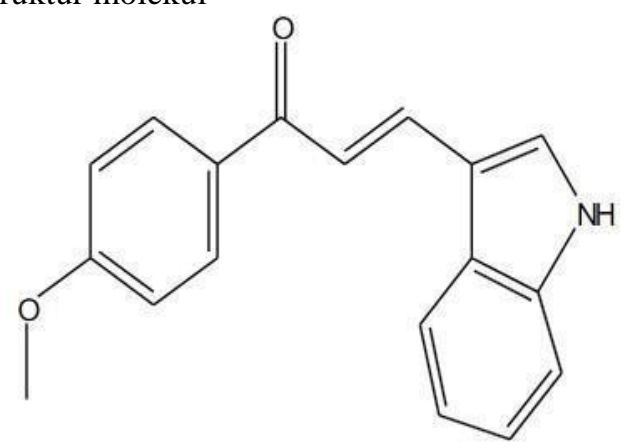

Gambar 4.9 Struktur Kimia senyawa(E)-3-(1Hindol

\section{Uji Aktivitas Antioksidan Isolat}

Pada uji aktivitas senyawa antioksidan isolat A dan isolat B dari ekstrak daun teh-tehan dilakukan dengan

$\begin{array}{llllll}\text { Sampel } & \text { Konsemtrasi }(\mathrm{ppm}) & \text { Replikasi } 1 & \text { Replikasi } 2 & \text { Replikasi 3 } & \text { Rata-Rata } \\ 10 & 0.1855 & 0.1657 & 0.1632 & 0.163633 & 47.16392 \\ 20 & 0.1739 & 0.1537 & 0.1577 & 0.155467 & 49.80088 \\ 30 & 0.162 & 0.1499 & 0.1513 & 0.1507 & 51.34001 \\ 40 & 0.155 & 0.1924 & 0.1902 & 0.1898 & 38.71489 \\ 50 & 0.1509 & 0.1811 & 0.1808 & 0.178033 & 42.51426 \\ 10 & 0.1868 & 0.1753 & 0.1764 & 0.1723 & 44.36552 \\ 20 & 0.1722 & 0.1693 & 0.1662 & 0.161567 & 47.83123 \\ 30 & 0.1652 & 0.1594 & 0.1583 & 0.149333 & 51.78129 \\ 40 & 0.1492 & 0.1902 & 0.1886 & 0.1881 & 39.2638 \\ 50 & 0.1303 & 0.1769 & 0.1783 & 0.176367 & 43.05242\end{array}$

menggunakan metode penangkapan radikal bebas DPPH. Diperoleh data seperti pada table 4.5. setelah itu dicari persamaan kurva kalibrasi antara konsentrasi (x) dan \%ES (y) maka diperoleh persamaan kurva kalibrasi dari isolate A yaitu $\mathrm{y}=0,309 \mathrm{x}+36,854$ sedangkan persamaan kurva kalibrasi isolate B yaitu $y=0,3145 x+35,607$. Setelah itu dihitung nilai $\mathrm{IC}_{50}$. Berdasarkan hasil uji yang dilakukan dapat diketahui bahwa isolat A memiliki nilai IC50 sebesar 42,54369 ppm sedangkan isolat B memiliki nilai IC50 sebesar 45,7647 ppm. Klasifikasi nilai efektivitas Isolat B senyawa antioksidan dilakukan berdasarkan nilai IC50 yang terdapat didalam senyawa tersebut. Suatu senyawa dikatakan memiliki aktivitas antioksidan yang sangat kuat apabila memiliki nilai IC50 < 50 ppm; kuat apabila memiliki nilai IC50 dalam nilai IC50>150 ppm (Fidrianny et al, 2014). Dengan demikian, isolat A dan B memiliki aktivitas

Tabel 4.5 Data Absorbasi Senyawa Uji pada Panjang Gelombang 517 nm

\section{Uji Aktivitas Antibakteri Isolat}

Pada uji aktivitas antibakteri dilakukan dengan menentukan nilai kadar hambat minimum isolat pada bakteri gram positif Staphylococcus aureus. Pengujian nilai KHM menunjukkan adanya media yang jernih tanpa disertai dengan endapan pada konsentrasi 1600 ppm dan 2000 ppm. Nilai kadar hambat minimum merupakan kadar senyawa uji minimum yang mampu rentang 50-100 ppm;

\section{Diameter zona}

\section{Konsentrasi (ppm) Penghambatan (cm) \\ Isolat A Isolat B}

\begin{tabular}{ccc}
\hline 200 & 1,60 & 1,52 \\
400 & 1,72 & 1,57 \\
600 & 1,75 & 1,66 \\
800 & 1,82 & 1,70 \\
1600 & 1,85 & 1,83 \\
2000 & 1,95 & 1,92 \\
Kontrol (+) & 2,67 & 2,55 \\
Kontrol (-) & &
\end{tabular}


sedang apabila memiliki nilai Nilai kadar bunuh minimum merupakan konsentrasi minimum senyawa uji yang dibutuhkan untuk membunuh populasi bakteri yang terkandung didalam media pertumbuhan. Rendahnya viabilitas bakteri yang tersisa dalam media pertumbuhan akan menyebabkan ketidakmampuan bakteri untuk tumbuh setelah diuji disk pada media agar menghambat pertumbuhan bakteri secara kasar mata. Pengamatan hasil uji mikrodilusi melalui antioksidan yang sangat kuat karena nilai IC50 < 50 ppm. pengamatan langsung menunjukkan hasil positif apabila medium tampak jernih selama masa inkubasi 24 jam. Hasil pengamatan tersebut tidak mampu menggambarkan persentase viabilitas sel yang masih terdapat pada medium pertumbuhan. Maka untuk penentuan nilai kadar bunuh minimum dilakukan dengan menggunakan metode difusi disk.

Tabel 4.6 Hasil Uji KBM pada isolat A

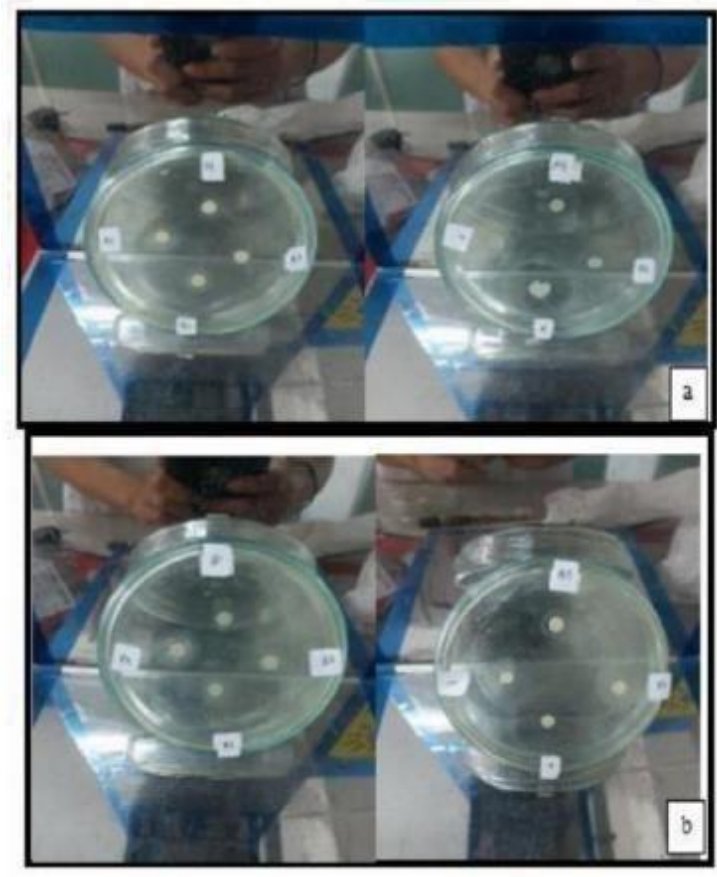

Gambar 4.10 Hasil Uji KBM pada Media Agar pada : a. Isolat A, b. Isolat B
Menurut Greenwood (1995) dalam Pratama (2005), respon hambatan pertumbuhan bakteri dapat diklasifikasikan sebagai berikut : memiliki aktivitas antibakteri yang kuat jika zona penghambatan $>2 \mathrm{~cm}$, sedang jika zona penghambatan 1,6-2 cm, lemah jika zona penghambatan 1-1,5 cm, dan kurang efektif jika zona penghambatan $<1 \mathrm{~cm}$. Berdasarkan hasil uji dapat diketahui bahwa isolat A dan B memiliki aktivitas antibakteri yang sedang yang tidak berbeda jauh secara signifikan. Selain itu, semakin tinggi konsentrasi isolat maka semakin besar pula zona penghambatannya. Pada kontrol positif memiliki aktivitas antibakteri kuat sedangkan kontrol negatif tidak memiliki aktivitas antibakteri.

\section{Hasil Penambatan Molekul Kesimpulan Hasil Penambatan Molekul}

Berdasarkan hasil penggabungan interpretasi data penambatan molekul pada jenis protein glutathione peroxidase (GPX), superoxide dismutase (SOD), peptidoglycan glycosyltransferase (PGT), dan DalanylDalanine carboxypeptidase (DACA) maka dapat diketahuibahwa semua jenis protein ini lebih kuat jika dibandingkan dengan aktivitas ligan asli. memiliki ikatan yang stabil dengan senyawa aktif dan memiliki aktivitas yang lebih kuat jika dibandingkan dengan aktivitas ligan asli.

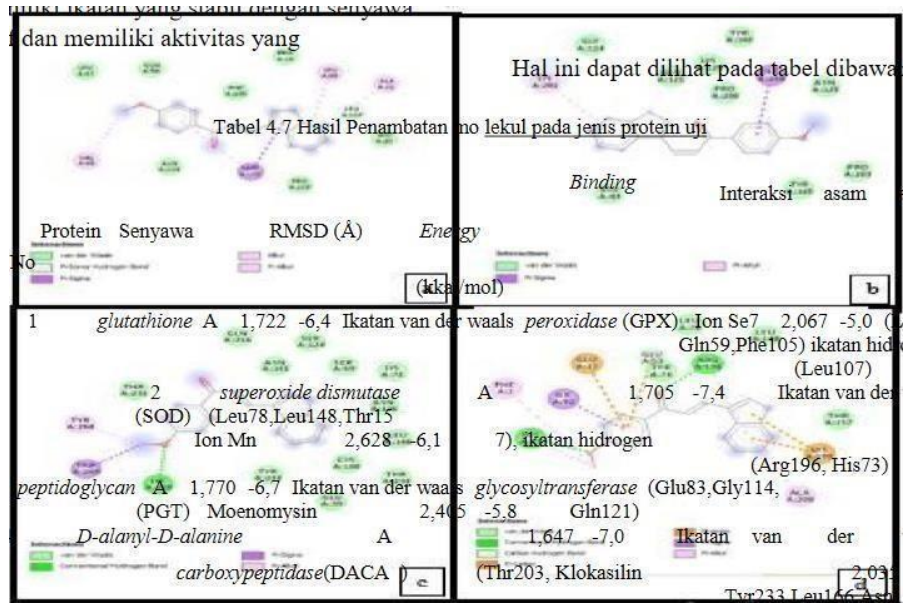

Gambar 4.11 Hasil Interaksi anatara Ligan dengan Protein secara 2D dari jenis molekul : a. GPX, b. PGT,

$$
\text { c.26), ikatan hidrogen }
$$

Ketika nilai RMSD dan nilai binding energy suatu ikatan semakin kecil maka ikatan tersebut semakin stabil dan memiliki aktivitas yang lebih kuat. Hal ini dapat diketahui dari beberapa perbandingan interaksi dari protein uji dengan senyawa A dan interaksi protein uji dengan liganasli.

\section{KESIMPULAN}

Berdasarkan hasil penelitian yang dilakukan pada isolat dari tumbuhan daun the-tehan maka dapat 
disimpulkan bahwa pada ekstrak daun teh-tehan (Acalypha siamensis) terdapat sebuah senyawa aktif yang berhasil diisolasi. Isolat aktif tersebut memiliki rumus kimia $\mathrm{C}_{18} \mathrm{H}_{15} \mathrm{NO}_{2}$ dengan nama kimia (E)-3(1Hindol3yl)1(4methoxyphenyl)-prop-2-en-1-one yang memiliki aktivitas antioksidan sangat kuat dengan nilai IC50 sebesar 42,54369 ppm dan memiliki aktivitas antibakteri sedang pada Staphylococcus aureus(bakteri gram positif) dengan nilai zona penghambatan $1,6-2 \mathrm{~cm}$ serta memiliki interaksi yang baik dengan protein PGX, SOD, PGT dan DACA sehingga berpotensi sebagai senyawa antioksidan dan antibakteri pada studi penambatan molekul secara in silico

\section{DAFTAR PUSTAKA}

Ahmadinejad, Fereshteh et al. 2017.

"Molecular Mechanisms behind Free Radical Scavengers Function against Oxidative Stress." Antioxidants 6(3): 51. http://www.mdpi.com/20763921/6/3/51. Akar, Zeynep, Murat Küçük, and Hacer Doğan. 2017. “A New Colorimetric DPPH•scavenging Activity Method with No Need for a Spectrophotometer Applied on Synthetic and Natural Antioxidants and Medicinal Herbs." Journal of

Enzyme Inhibition and Medicinal Chemistry 32(1): 640- 47. http://dx.doi.org/10.1080/14756366.2 017.1284068. Astuti, S., 2008. Isoflavon kedelai dan potensinya sebagai penangkap radikal bebas. Jurnal Teknologi Industri dan Hasil Pertanian, 13(2), pp. 126136. Azwanida, N.N. 2015. "A Review on the Extraction Methods Use in Medicinal Plants, Principle, Strength and Limitation.'Medicinal \&

Aromatic Plants04(03):3

http://www.omicsgroup.org/journals/a-

reviewontheextractionmethodsuseinmedicinalplantsprinciplest $\underline{\text { re }}$

ngthand -limitation-2167

04121000196.php?aid=58448. Coskun,Ozlem 2016. "Separation Techniques: Chromatography." 3(2): 156-60. Dallakyan, Sargis, and Arthur J Olson. 2015. 1263

Methods in molecular biology (Clifton, N.J.) SmallMolecule Library Screening by Docking with PyRx. Dye,

Christopher. 2015. "After 2015 : Infectious Diseases in a New Era of Health and Development." Philosophical Transactions of the Royal Society B 369(20130426). Ferreira, Leonardo G., Ricardo N. Dos Santos, Glaucius Oliva, and Adriano D. Andricopulo. 2015. 20 Molecules Molecular Docking and StructureBased Drug Design Strategies. Field, L. D., S. Sternhell, and J. R. Kalman. 2007. Organic Structures from Spectra. 4th ed. Chichester: John Wiley and Sons. Gibbons, Simon. 2012. "An Introduction to Planar Chromatography and Its

Application to Natural Products Isolation." In Natural Products Isolation, eds. Satyajit D. Sarker and Luftun Nahar. London: Humana Press, 117-54. Gwatidzo, L., Dzomba, P. \& Mangena, M., 2018. TLC separation and antioxydant activity of flavonoids from Carissa bispinosa, Fcus sycomorus, and Grewia bicolar fruits. Journal of Nutrire, 43(3), pp. 1-7. Hardjono, S., 2012. Modifikasi
Struktur 1(Benzoiloksi)urea dan Hubungan Kuantitatif StrukturAktivitas Sitotoksiknya, Surabaya: Universitas Surabaya. Hariana, A., 2013. Tumbuhan Obat dan Khasiatnya. Jakarta: Penebar Swadaya. Huang, Sheng You, and Xiaoqin Zou. 2010. "Advances and Challenges in Protein-Ligand Docking." International Journal of Molecular Sciences 11(8): 3016-34. Istyastono, E. P., Yuniarti, N. \& Jumina, 2009. Sintesis Senyawa Berpotensi sebagai Inhibitor Angiogenesis :

2benzilidenasikloheksana-1,3dion,. 20 ed. s.l.:Majalah Farmasi Indonesia. Jang, J. et al. 2017. "Environmental Escherichia Coli:Ecology and Public Health

Implications-a Review."Journal of Applied Microbiology 123(3): 570-81 Jensen, F., 2007. Introduction to Computational Chemistry. 2 ed. Denmark: 415-416. Leach, A. R., 2017. Molecular Modelling: Principles and Applications. s.l.:PrenticeHall, Inc.,

Englewood Cliffs, New Jersey. Liang, Ningjian, and David D. Kitts. 2014. "Antioxidant Property of Coffee Components: Assessment of Methods That Define Mechanism of Action." Molecules 19(11): 19180-208. Mukhriani. 2014. "Esktraksi Pemisahan Senyawa Dan Identifikasi Senyawa Aktif." journal Kesehatan VII(2): 361-67. Munadi, Ernawati. 2017. "Tanaman Obat, Sebuah Tinjauan Singkat." In Info Komoditi Tanaman Obat, eds. Zamroni Salim and Ernawati Munadi. Jakarta: Badan Pengkajian dan Pengembangan Perdagangan Kementerian Perdagangan Repiblik Indonesia, 1-8. Parija, Subhash Chandra. 2012. Textbook of Microbiology and Immunology. 2nd ed. Pudhucherry: Elsevier. Pavia, Donald L., Gary M. Lampman, George S. Kriz, and James R. Vyvyan. 2009. Introduction to Spectroscopy. 4th ed. Belmont: Cengage Learning. Pertiwi, T. Y., 2018. 
Aktivitas Antioksidan serta Korelasinya dengan Kadar Fenolik dan Flavonoid Total pada Enam Tanaman Hias. Jurnal Farmasi Indonesia. Sagun, V. G., G, A. L. \& Welsen, V., 2010. Revision and phylogeny of Acalypha (Euphorbiaceae) in Malesia. 55(1), pp. 21-60. Sanmugapriya, E. \& Venkataraman, S., 2006. Studies on hepatoprotective and antioxidant actions of Strychnospotatorium Linn. seeds on CCl4 induced acute hepatic injury in experimental rats. Journal Ethnopharmacology, 105(12), pp. 154-160. Seeliger, Daniel, and Bert L de Groot. 2010. "Ligand Docking and Binding Site Analysis with PyMOL and Autodock/Vina." Journal of computeraided molecular design 24(5): 417-22.

Shikha, Deepti, and Rita Awasthi. 2015. "Application of I.R. Spectroscopy \& Mass Spectrometry in Structural

Elucidation of Drugs." International Journal of Advanced

Research in Chemical Science 2(8): 38-45. www.arcjournals.org. Shriner, R. L. et al., 2004. The Systematic Identification of Organic Compounds. 8 ed.

s.l.:John Willey \& Sons Inc. Silverstein, M. et al., 2005. Spectrometri Identification of Organic Compounds. 7 ed.

s.1.:John Willey \& Sons Inc. Steenis, V. C. G., 2013. Flora. Jakarta: PT Balai Pustaka : 248 United State Pharmacopeia 40 National Formulary 35. 2017. Rockville: United States Pharmacopeial Convention. Wahyono, H., 2007. Peran Mikrobiologi Klinik Pada Penanganan Penyakit Infeksi., Semarang: Fakultas Kedokteran Universitas Diponegoro. Werdhasari, A., 2014. Peran antioksidan bagi kesehatan. Jurnal Biotek Medisiana Indonesi, 3(2), pp. 59-68. 